Avaliable online at http://e-journal.unipma.ac.id/index.php/gulawentah

\title{
MASJID TEGALSARI JETIS PONOROGO (MAKNA SIMBOLIK DAN POTENSINYA SEBAGAI SUMBER PEMBELAJARAN SEJARAH LOKAL)
}

\author{
Hadi Kusnanto, Yudi Hartono \\ 1,2) Program Studi Pendidikan Sejarah Universitas PGRI Madiun \\ Email: ${ }^{1)}$ hadikusnanto03@gmail.com, ${ }^{2}$ cahya_nadwa@yahoo.com
}

\begin{abstract}
Abstrak
Penelitian ini bertujuan untuk menganalisis dan mendeskripsikan makna simbolik arsitektur Masjid Tegalsari Jetis Ponorogo dan potensinya yang dapat dimanfaatkan sebagai sumber pembelajaran sejarah lokal. Penelitian ini menggunakan pendekatan penelitian kualitatif dengan jenis penelitian deskriptif kualitatif. Sumber data menggunakan sumber dan sekunder Pengumpulan data menggunakan teknik observasi, wawancara, dan dokumentasi. Analisis data menggunakan teknik coding model Strauss dan Corbin, dan keabsahan datanya dengan triangulasi. Hasil penelitian menunjukkan bahwa. Arsitektur Masjid Tegalsari merupakan akulturasi corak Jawa, Islam, dan Hindu. Unsur-unsur masjid; mihrab, bangunan utama, serambi, tiang, atap, batu bancik, gapura, dan pagarnya memiliki makna yang dalam sebagai tuntunan hidup. Makna-makna dari simbulnya berpotensi untuk dijadikan sebagai sumber pembelajaran sejarah lokal khususnya sejarah agama Islam. Dengan menjadikan lingkungan sekitar atau dinamika masyarakat yang berada di sekitar dimungkinkan peserta didik dapat mengkontektualkan pelajaran sejarah Islam sehingga mudah memahami dan menjadikannya sebagai edukasi, inspirasi, rekreasi, dan pada akhirnya tumbuh kesadaran sejarahnya.
\end{abstract}

Kata kunci: Masjid Tegalsari, makna simbolik, sumber pembelajaran

\section{Tegalsari Mosque JetisPonorogo (Symbolic Meaning and its Potential as Local History Learning Source)}

\begin{abstract}
The study aims to analyze and describe symbolic meaning of TegalsariJetisPonorogo Mosque architecture and its potential that can be used as learning sources of local history. It used descriptive qualitative research design. The source of data consisted of main and secondary data that were collected through observation, interview, and documentation. The data were analyzed using coding technique of Strauss and Corbin Model, and verified through triangulation. The results show that the architecture of Tegalsari Mosque is the product of the mixing of Java, Islam, and Hinduism culture. The mosque elements are mihrab (a place of Imam leading a pray), a main hall, a verandah, beams, roof, bancik stone, a gate, and fences that mean as a life guidance. The meaning of their symbols is potential to be learning sources for the local history, especially Islamic history. By using the mosque's surrounding or dynamic situation of the society in the surrounding, it assumes that the students can learn Islamic history contextually. It is, therefore helping the students to understand more and make the historical place to be parts of education, inspiration and recreation. Further, the students' historical awareness can be built.
\end{abstract} Keywords: Tegalsari Mosque, symbolic meaning, learning sources 
gulawentah: Jurnal Studi Sosial

Volume 2 Nomor 1 Juli 2017 hal 41-48

Avaliable online at http://e-journal.unipma.ac.id/index.php/gulawentah

\section{Pendahuluan}

Indonesia adalah negara kepulauan terbesar di dunia yang mempunyai penduduk terbesar keempat dunia. Indonesia juga tercatat sebagai negara yang berpenduduk Muslim terbesar di dunia. Indonesia secara geografis dan geopilitis berada pada posisi silang dunia yang menghubungkan berbagai benua dan samudra, sehingga menjadi tempat persilangan jalur lalu lintas dan perdagangan laut. Sejak zaman kuno Indonesia telah memiliki peranan penting dalam menghubungkan pelayaran dan perdagangan antara Benua Timur dan Benua Barat, antara Cina dan India serta bangsa-bangsa Asia di bagian yang lebih Barat lagi seperti bangsa Persia dan Arab. Posisi silang geografis yang demikian juga akan menjadikan Indonesia sebagai tempat persilangan arus peradaban dunia.

Sejarah mencatat masuknya tiga pengaruh besar dari agama dan peradaban dunia yang ikut menentukan irama dan perubahan sejarah bangsa Indonesia serta sekaligus memberikan corak, warna dan nuansa yang berbeda untuk masing-masing kurun waktu. Tiga pengaruh besar yang dimaksud ialah agama dan peradaban Hindu, agama dan peradaban Islam, dan peradaban Barat.

Islam memiliki pengaruh yang signifikan dalam tatanan kehidupan di nusantara. Ada beberapa saluran penyebarannya yaitu melalui perdagangan, perkawinan, dakwah Islam, pendidikan, dan kesenian. Menurut Daliman (2012:39) masuk dan meluasnya Islam ke Indonesia berjalan secara damai dan penuh toleransi. Salah satu sebabnya ialah karena pedagangpedagang yang menyebarkan Islam di Indonesia adalah pedagang-pedagang dari Gujarat India yang tidak fanatik sifatnya. Hurgronje (dalam Paeni, 2009: 66) menjelaskan proses Islamisasi yang terjadi secara damai disebabkan oleh daya tarik agama Islam itu sendiri bagi masyarakat Indonesia.

Islam sebagai sebuah agama memiliki tempat ibadah yaitu masjid. Juliadi (2007:54-55) menyatakan bahwa bentuk-bentuk masjid di Indonesia tidak terlepas dari pengaruh arsitektur masjid dunia Islam yang dipadukan dengan kondisi kebudayaan yang ada, bahkan juga dengan unsur-unsur budaya prasejarah yang ada sebelum HindhuBudha, turut mewarnai arsitektur masjid Indonesia yang kembali kepada tradisi bangunan kayu. Penggunaan kembali tradisi lama tersebut karena kondisi kebudayaan pada waktu itu kurang menguntungkan untuk mendirikan bangunan-bangunan yang megah dan serba besar dengan nilai-nilai monumental.

Daliman (2012: 61) juga menyatakan bahwa gaya arsitektur masjid di Indonesia nampak dalam bentuk atapnya yang bertingkat lebih dari satu yang disebut atap tumpang. Jumlah tumpang itu selalu ganjil (gasal), biasanya tiga dan juga ada kalanya sampai lima seperti pada Masjid Banten. Bentuk atap tumpang pada bangunan ini jelas menunjukkan adanya suatu kelanjutan dari seni bangunan tradisional Indonesia kuno. Atap tumpang sampai saat ini masih digunakan di Bali, terutama untuk 
mengatapi bangunan-bangunan pada bagian tersuci di dalam pura (kuil). Atap tumpang yang demikian disebut meru. Juga pada relief-relief candi di Jawa Timur seperti Candi Jago didapatkan pula bentuk atap tumpang.

Salah satu masjid yang tertua di Jawa Timur yaitu Masjid Tegalsari Kecamatan Jetis Kabupaten Ponorogo. Masjid tersebut didirikan sekitar abad ke-18. Tegalsari awalnya berupa hutan yang dibuka oleh dua saudara yaitu Pangeran Sumende dan Kyai Donopuro untuk membangun masjid dan pesantren. Salah satu santri yang belajar saat itu bernama Muhammad Besari dari Caruban yang terkenal sangat pandai. Lalu ia dijadikan menantu oleh Kyai Nursalim dari Mantub Ngasinan. Kemudian Muhammad Besari diberi tanah oleh kyai Donopuro di sebelah timur Dusun Setono yang selanjutnya didirikan Masjid dan Pesantren Tegalsari. Pada awalnya Desa Tegalsari dipimpin oleh lurah dan juga tokoh panutan yang bergelar "Kyai Ageng". Pada waktu itu terjadi Geger Pecinan di Keraton Mataram Kartosuro dipimpin oleh raden Mas Garendi yang kemudian dapat menduduki istana. Paku Buwono II Raja Mataram saat itu mengungsi ke Ponorogo dan singgah di Desa Tegalsari. Beliau menyusun kekuatan dan akhirnya dapat memadamkan pemberontakan. Sebagai balas budi Desa Tegalsari dijadikan perdikan dan Kepala Desa Tegalsari diberi gelar "Kyai Ageng", yang dimaksud adalah Kyai Ageng Muhammad Besari putra Kyai Anom Besari dari Kuncen.

Masjid Tegalsari ini mempunyai keunikan, kekunoan, arsitektur, simbol- simbol yang penuh makna. Namun tidak banyak orang yang mengetahui dan memahami nilai-nilainya. Padahal nilainilai memiliki fungsi sebagai penuntun tindakan dan perilaku manusia. Nilainilai juga menjadi sumber materi dalam menumbuhkan kesadaran sejarah khususnya sejarah lokal. Sehingga menimbulkan pertanyaan: (1) Apa makna simbolik arsitektur Masjid Tegalsari Jetis Ponorogo?, (2) Apa saja potensi-potensi yang terkandung dalam Masjid Tegalsari Jetis Ponorogo yang dapat dimanfaatkan sebagai sumber pembelajaran sejarah lokal?. Guna mejawab pertanyaan tersebut perlu dilakukan peelitian.

Masjid berasal dari bahasa Arab: sujudan, fi'il madinya sajadah (ia sudah sujud). Kata sajadah diberi awalan $m a$, sehingga menyebabkan perubahan bentuk sajadah menjadi masjidu, masjid (Juliadi, 2007: 3). Kemudian Suherman (2012: 61) secara terminologis masjid mengandung makna sebagai pusat dari segala kebajikan kepada Allah SWT, di dalamnya terdapat dua kebajikan yaitu kebajikan yang dikemas dalam bentuk ibadah khusus yaitu shalat fardhu, baik secara sendirian maupun berjamaah dan kebajikan yang dikemas dalam bentuk amaliyah sehari-hari (untuk) berkomunnikasi dan bersilahturahmi dengan sesama jama'ah.

Menurut Dwi Hastoro (dalam Juliadi 2007:7) kata masjid mempunyai pengertian tertentu yaitu suatu bangunan atau gedung atau suatu lingkungan yang yang ditembok untuk digunakan sebagai tempat menunaikan shalat, baik shalat lima waktu, maupun shalat Jum'at atau shalat hari raya. 
Pengertian masjid sebagai bangunan atau kompleks bangunan merupakan wujud dari aspek fisik dalam kebudayaan Islam.

Sumalyo (dalam Juliadi 2007: 4142) mengatakan bahwa arsitektur merupakan hasil proses perancangan dan pembangunan oleh seseorang atau sekelompok orang dalam memenuhi kebutuhan ruang untuk melaksanakan kegiatan tertentu. Berdasarkan pengertian tersebut dan batasan yang dimaksud dengan masjid, maka secara umum arsitektur masjid adalah bangun untuk sembahyang bersama pada hari Jum'at dan ibadah Islam lainnya dengan fungsi majemuk sesuai dengan perkembangan zaman, budaya dan tempat suatu masyarakat.

Masjid sebagai bangunan untuk sembahyang pada dasarnya berada dalam satu kesatuan dengan mendengarkan ceramah agama (khutbah). Oleh karena itu selain mempunyai ruang untuk shalat bersama (liwan), masjid dilengkapi denagn mimbar, mihrab, dan beberapa elemen bangunan lainnya. Pada perkembangannya masjid mempunyai keanekaragaman dalam wujudnya, namun pada umumya bagian-bagian masjid tidak banyak berubah secara drastis. Bagian-bagian tersebut menurut Juliadi (2007: 43-50) yaitu; mihrab, mimbar, liwan. maksurah dan zawiyah, kubah, serta menara.

$$
\text { Paeni (2009: }
$$
mengatakan bahwa di Indonesia terdapat berbagai macam masjid yang dapat dibedakan menjadi empat jenis yaitu (1) langgam atau gaya tradisional dengan ciri utamanya atap bersusun (tumpang),
(2) langgam romantik yang dicirikan dengan menggunakan kubah sebagai atap masjid, biasanya berukuran besar, dan sering juga ditambah dengan rangkaian busur lengkung di serambinya, (3) langgam modernisme, masjid berusaha meninggalkan semua idiom dan ikon tradisional dan lama, bentuk-bentuk yang lahir sepenuhnya baru. Justru karena ini masjid berlanggam ini tidak banyak dihargai oleh khalayak, dan (4) langgam eklektik atau campuran, langgam ini dapat dipadatkan dengan tiga tuntutannya yakni, pan-Islamisme, masa kini, setempat.

Masjid sebagai hasil budaya tentunya berkaitan dengan nilai-nilai yang terpesan dalam simbol sebagai penanda atau penciri yang memberitahukan sesuatu hal kepada seseorang (Herusatoto 2008: 17). Saifuddin (2006: 289) mengartikan simbol adalah objek, kejadian, bunyi bicara, tau bentuk-bentuk tertulis yang diberi makna manusia. Dalam Kamus Logika Dictionary of Logic (dalam Herusatoto 2008: 17) simbol adalah tanda buatan yang bukan berwujud katakata untuk mewakili atau menyingkat sesuatu artian apapun. Jadi simbol adalah suatu tanda yang mempunyai arti untuk menyatakan sesuatu hal kepada seseorang. Peursen (dalam Herusatoto 2008: 20-22) menguraikan pengertian dan proses terwujudnya simbol atau lambang dalam kebudayaan manusia antara lain; (1) Sejumlah pengarang membedakan antara tanda dan simbol atau lambang. Tanda mempunyai pertalian tertentu dan tetap dengan apa yang ditandai, (2) Terdapat simbol yang 
terbina selama berabad-abad, (3) Lambang-lambang mengejawantahkan proses belajar, sehingga kita seolah-olah dapat naik menara lalu memandang daerah-daerah yang luas yang dulu tidak kita kenal lalu juga tahu arah mana kita harus berkiblat, (4) Lambang-lambang memperlihatkan sesuatu dari kaidah yang berlaku dalam perbuatan manusiawi,pengertian dan ekspresi. Kaidah tersebut tidak hanya bertalian dengan akal budi dan pengertian manusia, tetapi dengan seluruh pola kehidupannya,seluruh perbuatan,dan harapan manusia, (5) Lambang-lambang terdapat di luar badan manusia dan tidak terikat oleh naluri jasmaniah. Simbol muncul bila manusia sedang belajar atau bila proses belajar sedang berlangsung menampilkan materi untuk mencapai suatu tingkatan emosi tertentu dari pengunjung (Yoeti, 2006: 14).

\section{Metode Penelitian}

Penelitian ini dilaksanakan di Masjid Tegalsari Desa Tegalsari Kecamatan Jetis Kabupaten Ponorogo mulai bulan Februari sampai dengan Juli 2016.

Sumber data yang digunakan bersifat primer dan skunder yang deiambil dengan wawancara, observasi, dan pencatatan dokumen. Infforman ditentukan dengan teknik sowball sampling. Instrumen utama dalam penelitian ini adalah peneliti sendiri. Data yang diperoleh dianalisis dengan teknik coding model Strauss dan Corbin, dan keabsahan datanya dengan triangulasi.

\section{Hasil dan Pembahasan}

\section{Corak dan Perkembangan Bangunan Masjid Tegalsari \\ Corak bangunan Masjid Tegalsari} merupakan akulturasi dari agama Islam, Jawa, dan Hindu. Masjid Tegalsari pertama dipugar oleh Pemerintah dan diresmikan oleh Presiden Soeharto pada tahun 1978. Pemugaran ini yang memberi sentuhan modern di depan serambi masjid, perluasan lahan di depan masjid, dan mengganti genteng asli yang berbentuk sirap dengan genteng biasa. Pemugaran yang kedua dipugar oleh Dinas Purbakala Jawa Timur pada 1997. Pemugaran ini adalah mengganti tembok yang sudah tua dan pengembalian kembali bentuk asli genteng yang awalnya berbentuk sirap, hal ini dilakukan untuk menjaga keaslian bangunan.

\section{Makna Simbolik Masjid Tegalsari}

Makna simbolik Masjid Tegalsari dapat dijelaskan dari unsur-unsur bangunannya, yaitu:

1. Mihrab Masjid Tegalsari. Mihrab sebagai tempat mimbar untuk berkhutbah tertulis angka tahun 1700 dan ukiran-ukiran daun. Hal tersebut memiliki makna bahwa mimbar yang berarti kursi atau singgasana melambangkan sebuah kehormatan khotib dalam menyampaikan khotbah, pembuatan mimbar di dalam masjid yang menyerupai singgasana juga mempunyai makna posisi Khotib di mimbar layaknya seorang raja yang sedang memberikan sabda atau arahan terhadap rakyatnya. Mihrab tersebut dibuat tahun 1700 dan melambangkan kesuburan, kentraman, dan kejayaan umat Islam 
Avaliable online at http://e-journal.unipma.ac.id/index.php/gulawentah

dalam melaksanakan ibadah dan saat menjalani kehidupan dunia serta akhirat.

Dua buah lampu berbentuk lonceng, lonceng adalah sebuah alat yang bisa menghasilkan bunyi maka artinya sebagai tanda bahwa urusan manusia dengan Tuhan adalah yang paling utama untuk dilakukan. Sehingga umat Islam wajib beribadah dan selalu mendirikan tiang agama yaitu shalat. Lampu yang memancarkan sinar atau cahaya berarti cahaya Tuhan yang menyinari dunia ini, sehingga kita sebagai makhluk ciptaanya harus senantiasa ingat akan karunia dan nikmatNya. Makna Mihrab yang berbentuk lorong, mempunyai makna gua dunia yang berisi Yang Esa (Satu) dan menandakan kehadiran Tuhan di dunia ini.

2. Ruang utama Masjid Tegalsari terdapat tiang berjumlah 36 yang jika ditambahkan $3+6=9$, mempunyai filosofi Wali Songo yang menyebarkan Islam di Jawa.

3. Serambi Masjid Tegalsari disangga tiang yang memiliki 12 tiang yang berjajar 6 tiang kiri dan kanan mengandung arti yaitu melambangkan Rukun Iman dalam Islam yang berjumlah 6 .

4. Batu "bancik" Masjid Tegalsari merupakan batu pijakan kali yang terletak di depan masjid. Batu tersebut terdapat tulisan namun sudah bisa dibaca namun para informan menjelaskan bahwa batu tersebut peninggalan jaman Hindu. Batu tersebut menggambarkan selesai era
Majapahit Hindu menggambarkan dan berganti era Islam.

Batu "bancik" yang posisinya terbalik juga mengandung arti bahwa masyarakat yang menganut ajaran Hindu di bawah kekuasaan Kerajaan Majapahit seiring berdirinya Masjid Tegalsari dan pondok pesantren sudah berada di bawah kendali ajaran agama Islam yang disebarkan oleh Kyai Ageng Muhammad Besari.

5. Atap Masjid Tegalsari berbentuk tumpang tiga memiliki makna tiga hal yang harus dimiliki oleh umat Islam dalam kehidupannya yaitu Iman, Islam, dan Ihsan. Atap bangunan masjid berupa atap tumpang tiga juga dapat diartikan sebagai tiga amalan yang harus dilakukan oleh manusia yang hidup di dunia yaitu syariat, hakekat, dan makrifat.

6. Pagar berbentuk cembung, melengkung, dan menjorok keluar memiliki makna pencegahan atas kejadian yang terjadi sebelumnya yakni ketika pagar masih lurus jika naik sepeda tidak turun akan celaka atau jatuh akhirnya pagar dan jalan di depan dibuat berkelok sampai sekarang. Selain itu sebagai wujud perlindungan terhadap umat Islam yang sedang beribadah, lindungan ini diberikan oleh Allah SWT dari kaumkaum kafir dan godaan setan-setan.

7. Gapura sebagai tempat masuk jama'ah yang terdepat tepat di depan masjid mengandung arti ampunan dosa (gapura, bahasa arab ghofuro) hal ini dapat dikaitkan jika ada orang dengan niat baik masuk Islam, maka dosanya akan diampuni oleh Allah. 
gulawentah: Jurnal Studi Sosial

Volume 2 Nomor 1 Juli 2017 hal 41-48

Avaliable online at http://e-journal.unipma.ac.id/index.php/gulawentah

Potensi Masjid Tegalsari sebagai Sumber Pembelajaran Sejarah Lokal

Masjid Tegalsari dapat dijadikan sebagai sebagai pembelajaran sejarah lokal. Dengan mengetahui makna simboliknya, peserta didik dapat memahami dinamika sosial kegamaan masyarakat lokal sebagai bagian dari dinamika masyarakat bangsa terutama masuk, berkembang, dan pengaruhnya terhadap masyarakat nusantara.

Unsur-unsur Masjid Tegalsari memiliki makna yang dalam yang dapat dijadikan sebagai sumber pembelajaran sejarah yang berguna untuk pendidikan, inspirasi, instruktif, dan rekreatif sehingga generasi penerus atau peserta didik memiliki kesadaran sejarah.

\section{Pembahasan}

Masjid Tegalsari merupakan salah satu peninggalan masjid kuno yang corak bangunannya diwarnai oleh budaya lokal Jawa dan Hindu. Hal tersebut tampak pada atap masjid berbentuk tumpang terdiri dari tiga tingkatan yang atapnya semakin ke atas semakin mengecil, terdapat mihrab, terdapat serambi, halaman sekitar masjid dikelilingi oleh tembok dengan pintu gerbang, dibangun di sebelah barat pusat pemerintahan, dan terdapat selokan di depan masjid. Hal ini sejalan dengan teori tentang arsitektur masjid kuno di Indonesia oleh Pijper.

Pijper (dalam Juliadi 2007: 59-61) menyampaikan bahwa arsitektur masjid kuno Indonesia memiliki ciri khas yang membedakannya dengan bentuk-bentuk masjid di negara lain, dengan merujuk tipe masjid Indonesia yang berasal dari Jawa, maka Pijper menyebutnya tipe
Masjid Kuno Jawa dengan ciri-ciri; denahnya berbentuk segi empat, fondasi bangunan berbentuk persegi dan pejal (massive) yang agak tinggi, atap masjid berbentuk tumpang, terdiri dari dua sampai lima tingkat yang semakin ke atas semakin mengecil, di sisi barat atau barat laut terdapat bangunan yang menonjol sebagai mihrab, di bagian depan dan kadang-kadang di kedua sisinya ada serambi yang terbuka atau tertutup, halaman sekitar masjid dikelilingi oleh tembok dengan satu atau dua pintu gerbang, dibangun di sebelah barat alun-alun, arah mihrab tidak tepat ke kiblat, dibangun dari bahan yang mudah rusak, terdapat parit air yang mengelilinginya atau di depan masjid, awalnya dibangun tanpa serambi, dibangun di atas tiang kolong.

Unsur-unsur bangunan Masjid Tegalsari memiliki makna yang dalam sebagai rujukan untuk menjalani hidup. Hal tersebut potensial untuk dijadikan sumber pembelajaran sejarah lokal khususnya tentang sejarah agama Islam di Ponorogo. Makna-makna simbolik masjid dalam konteks pembelajaran sejarah bermanfaat sebagai edukatif, inspiratif, dan rekreatif sehingga peserta didik memiliki kesadaran sejarah, beragama, bermasyarakat, dan berbangsa.

\section{Kesimpulan}

Arsitektur Masjid Tegalsari merupakan akulturasi corak Jawa, Islam, dan Hindu. Unsur-unsur masjid; mihrab, bangunan utama, serambi, tiang, atap, batu bancik, gapura, dan pagarnya memiliki makna yang dalam sebagai tuntunan hidup. Makna-makna dari 
gulawentah: Jurnal Studi Sosial

Volume 2 Nomor 1 Juli 2017 hal 41-48

Avaliable online at http://e-journal.unipma.ac.id/index.php/gulawentah

simbulnya berpotensi untuk dijadikan sebagai sumber pembelajaran sejarah lokal khususnya sejarah agama Islam.

Dengan menjadikan lingkungan sekitar atau dinamika masyarakat yang berada di sekitar dimungkinkan peserta didik dapat mengkontektualkan pelajaran sejarah Islam sehingga mudah memahami dan menjadikannya sebagai edukasi, inspirasi, rekreasi, dan pada akhirnya tumbuh kesadaran sejarahnya.

\section{Daftar Pustaka}

Daliman, A. (2012). Islamisasi dan Perkembangan KerajaanKerajaan Islam di Indonesia. Yogyakarta: Ombak.

Herusatoto, B. (2008). Simbolisme Jawa. Yogyakarta: Ombak.

Juliadi. (2007). Masjid Agung Banten: Nafas Sejarah dan Budaya. Yogyakarta: Ombak.

Paeni, M (ED.). (2009). Sejarah Kebudayaam Indonesia: Arsitektur. Jakarta: Rajawali Pers.

Suherman, E. (2012). Manajemen Masjid: Kiat Sukses Meningkatkan Kualitas SDM Melalui Optimalisasi Kegiatan Umat Berbasis Pendidikan Berkualitas Unggul. Jakarta: Alfabeta. 